large nodule of pyrope garnet from the Premier diamond mine of South Africa, and a fine rounded water-worn crystal of parti-coloured tourmaline, sectioned to show the colour. The Museum has acquired a large water-worn crystal of topaz of gemstone quality, about eight inches in diameter, with a cleavage plate of the same mineral, from Brazil. The weight of the larger specimen is $29 \frac{1}{2} \mathrm{lb}$. Other important acquisitions include the late Dr. $H$. Bolton's valuable collection of Carboniferous insect wings, presented recently to the Department of Palæontology.

\section{Thunder Census Organisation}

THE survey of thunderstorms in the British Isles during the coming summer is to be continued and again the co-operation of readers of Nature in the observational work is requested. Fuller details can be obtained from Mr. S. Morris Bower, Langley Terrace, Oakes, Huddersfield. The census has recently been extended into the winter months in order to bring the winter data, collected between 1925 and 1929, more nearly up to the standard of the summer survey, and also to make special reports on individual storms available for insurance and other purposes throughout the year. The lightning damage survey has been commenced in some parts of the country, and it is intended to build up this work gradually: sections of maps, on the scale of two miles to the inch, are issued to observers, who are invited to record local positions of damage.

\section{Awards for Aeronautical Research}

AT a meeting of the Council of the Royal Aeronautical Society held on April 21, the following awards were made: Silver Medal of the Society to Mr. B. N. Wallis, for his work on geodetic construction ; Simms Gold Medal to Mr. W. S. Farren, for his inventions of new methods of the measurement of drag and his designs of scientific apparatus for aeronautical research; Taylor Gold Medal to Mr. E. F. Relf, for his paper read before the Society on the compressed air tunnel; Sir Charles Wakefield Gold Medal to Mr. C. R. Fairey, for his work on the development of flaps; Busk Memorial Prize to Mr. R. P. Alston, for his paper read before the Society on wing flaps and other devices as aids to landing. At a meeting of the Amulree Committee held on April 27, the following awards were made on the recommendation of the Council of the Royal Aeronautical Society : British Gold Medal for Aeronautics to Dr. Hugo Eckener for his technical achievements in lighter-than-air craft; British Silver Medal for Aeronautics to Mr. A. J. Rowledge, for his scientific achievements in the development of aircraft engines.

\section{Announcements}

THE Council of the Royal Society of Edinburgh has awarded the Keith Prize for the period 1933-35 to Prof. Lancelot T. Hogben, for his papers on genetical subjects published alone and in collaboration, which have appeared in the Proceedings of the Society during the period of the award; and the Neill Prize for the period 1933-35 to Dr. Samuel Williams,
University of Glasgow, for his contributions to the anatomy and experimental morphology of the Pteridophyta.

Dr. W. E. Harper, of the Dominion Astrophysical Observatory, Victoria, B.C., who has been assistant director since 1923, has been appointed director in succession to Dr. J. S. Plaskett, who retired last year. Dr. J. A. Pearce, astronomer at the Observatory since 1924, has been made assistant director.

IN 1935 the directors of Teyler's Foundation and the members of Teyler's Second Society at Haarlem, Netherlands, announced a competition for a gold medal to be awarded for the best treatise on the interaction between atomic nuclei and electrons. Four essays were submitted, two from the United States and two from the Netherlands. The medal has now been awarded to Dr. H. B. G. Casimir, of Leyden. The prize essay will be published shortly in the Transactions of Teyler's Second Society and in the Archives du Musée Teyler.

THE twelfth Annual Norman Lockyer Lecture of the British Science Guild will be given by the Right Hon. Lord Rutherford on November 12. The lecture will be held in the Goldsmiths' Hall, Foster Lane, E.C.2 (by courtesy of the Goldsmiths' Company).

The forty-seventh Annual Conference of the Museums Association will be held at Leeds on July 6-10, under the presidency of Sir Eric Maclagan. Further information can be obtained from Mr. E. W. Wignall, Chaucer House, Malet Place, London, W.C.1.

The Medical Research Council will consider applications submitted by June 1 for a number of travelling fellowships in medical science (including clinical medicine and surgery) tenable abroad during the ensuing academic year. These will be awarded either by the Council or by other bodies on the Council's nomination, and will each be of the value of $\{400$, with an additional allowance for travelling and special expenses. Applications will at the same time be received for other travelling fellowships restricted respectively to tuberculosis and to psychiatry or neurology. Further information can be obtained from the Secretary of the Medical Research Council, 38 Old Queen Street, Westminster, London, S.W.1.

Sir Frederick Banting, Mr. Havelock Ellis and Dr. Robert Leiper were elected fellows of the Royal College of Physicians of London on April 30 by By-law xxxviII $(b)$.

Prof. Sigmund Freud, extraordinary professor of nervous pathology in the University of Vienna and well-known for his work on psychopathology and psychoanalysis, celebrated his eightieth birthday on May 6.

Prof. Hugo Spatz, professor of psychiatry in the University of Munich and senior physician to the Psychiatric Clinic, has been nominated to succeed Prof. Oskar Vogt as director of the Kaiser Wilhelm Institut für Gehirnsforschung at Berlin-Buch. 
A Discussion on "The Present Status of the Theory of Natural Selection" will be held at the Royal Society on May 14 at 4.30. It will be opened by Prof. D. M. S. Watson.

Tre annual Canadian Chemical Convention will be held at the Brock Hotel, Niagara Falls, Ontario, on June 9-11. British chemists who are likely to be in Canada at that time are advised to communicate with Dr. R. T. Elworthy, secretary of the Canadian Institute of Chemistry, 366 Adelaide Street West, Toronto, 2, Canada.

THE general meeting of the International Association for the Prevention of Blindness and of the International Organisation of the Campaign against Trachoma will be held at the Centre Marcelin Berthelot, 28 bis rue Saint-Dominique, Paris, on May 11 under the presidency of Prof. F. de Lapersonne. Further information can be obtained from the General Secretary, 66 Boulevard SaintMichel.

AT the anniversary meeting of the Royal Society of South Africa held on March 18, the following officers were elected for 1936: President, Prof. L. Crawford; Hon. Treasurer, Prof. A. Brown; Hon. General Secretary, A. J. H. Goodwin; Hon. Editor of Transactions, Prof. R. S. Adamson; Hon. Librarian Prof. E. Newbery; Council, K. H. Barnard, H. G. Fourcade, J. Jackson, R. F. Lawrence, Dr. E. P. Phillips, Dr. A. W. Rogers, Dr. B. F. J. Schonland, Prof. R. B. Young.

The March issue of Film Progress forms a Supplementary Bulletin to the "National Encyclopædia of Educational Films" (see NAture, Dec. 28, 1935, p. 1007). It gives an account of the advance that has been made in the use of educational films in 1935, and brings the Encyclopædia of films up to date.

IT was stated in NATURE of May 2, p. 737, that the Royal Society possessed no bust of Faraday prior to Sir Robert Hadfield's recent gift. We are informed that this is incorrect. Dr. H. Bence Jones, F.R.S., presented to the Royal Society in 1873 a marble bust of Faraday by the sculptor, M. Noble; and in 1885 the Royal Society acquired a plaster bust which had been made by J. H. Foley, R.A.

Is reviewing Bodenheimer's "Animal Life in Palestine" in Nature of January 4, p. 5, Prof. P. A. Buxton referred to the name 'scheltopusik'. Dr. B. N. Schwanwitsch, Entomological Laboratory, University of Leningrad, states that this is a native Russian name for the glass-snake (Ophisaurus apus Pall.), meaning literally 'yellow-bellied', which has been used in French and German zoological literature. This is, of course, no reason for its use in a work published in English, in which the reviewer also recognised German and Arabic names.
Applications are invited for the following appointments, on or before the dates mentioned :

A lecturer in engineering or mining technology in the Clowne Mining and Technical Institute, Clowne, Chesterfield-The Clerk to the Governors (May 16).

A head of the Engineering Department and a head of the Domestic Science and Women's Department in the Stockton-on-Tees Technical School Evening Institute-The Director of Education, Shire Hall, Durham (May 16).

A lecturer in pharmacy in the Witwatersrand Technical College, Johannesburg-Messrs. Frank Ross and Co., 9 Fenchurch Avenue, London, E.C.3 (May 16).

A lecturer in pathology and bacteriology in the Veterinary College, Madras-_The High Commissioner for India, General Department, India House, Aldwych, London, W.C.2 (May 16).

A head of the Engineering Department of the Cheltenham Technical College-The Secretary (May 16).

An assistant lecturer in zoology and chemistry in the City Technical College, Liverpool-The Director of Education, Education Offices, 14 Sir Thomas Street, Liverpool, 1 (May 19).

A demonstrator in physiology in the London (Royal Free Hospital) School of Medicine for Women, 8 Hunter Street, W.C.1-The Secretary (May 20).

A lecturer in bacteriology in the University of Liverpool-The Registrar (May 22).

A lecturer in physiology and a lecturer in zoology in the Brighton Technical College-The Education Officer, 54 Old Steine, Brighton (May 22).

An assistant in the Royal Observatory, Greenwich - The Secretary of the Admiralty (C.E. Branch), Whitehall, London, S.W.1 (quote C.E. 6235/35) (May 23).

A lecturer in engineering in the Leicester College of Technology-The Registrar (May 23).

A professor of mining and head of the Department of Mining and Fuels in University College, Notting. ham-The Registrar (May 25).

A civilian education officer (Grade III) in the Royal Air Force Educational Service-The Secretary (A.E.), Air Ministry, Adastral House, Kingsway, London, W.C.2 (May 25).

A lecturer in mathematics at the Goldsmiths' College, New Cross, S.E.14 The Warden (May 25).

A temporary information officer in the library of the Research Association of British Flour-MillersThe Director of Research, Old London Road, St. Albans.

An assistant engineer (civil) in the Malayan Publia Works Service-The Crown Agents for the Colonies, 4 Millbank, London, S.W.1 (quote M/4163).

Resident engineers for the construction of new aerodromes by the Air Ministry--The Secretary (W.B. 9), Air Ministry, Adastral House, Kingsway, London, W.C.2.

Structural engineering assistants in the Designs Branch of the Directorate of Fortifications and Works-The Under-Secretary of State (C. 5), The War Office, London, S.W.1. 